\title{
PHOSPHOROUS FORMS IN CULTIVATED INDIAN BLACK EARTH (ANTHROSOLS) OF VARYING TEXTURE IN THE BRAZILIAN AMAZON(1)
}

\author{
Kleberson Worslley de Souza ${ }^{(2)}$, Hedinaldo Narciso Lima ${ }^{(3)}$, Carlos Ernesto \\ G.R. Schaefer ${ }^{(4)}$, Wenceslau Geraldes Teixeira ${ }^{(5)}$, Karina Pulrolnik ${ }^{(6)}$ \& \\ Guilherme Resende Corrêa ${ }^{(7)}$
}

\begin{abstract}
SUMMARY
Despite the agricultural importance of Indian Black Earth (IBE) in the Amazon region, there are few studies that report on the relation between soil texture and chemical fertility of IBE. These soils of pre-Colombian origin, with high contents of $\mathrm{P}, \mathrm{Ca}$ and other nutrients are found across the Amazon valley. IBE profiles were studied to evaluate the total contents of $P$, its primary chemical forms and the $P$ transformation phases in areas with IBE soils of variable texture and in adjacent reference soils. The soil texture strongly influenced soil fertility, changing in terms of transformation of the primary $P$ forms and, consequently, predominant $P$ forms in IBE. Soils with texture varying between clay and heavy clay had higher total $P$ contents and primary Ca-P forms. Highest $\mathrm{P}-\mathrm{Al}$ and lowest total $\mathrm{P}$ amounts were observed at the site Rio Preto da Eva, where texture varies from sandy loam to sandy clay loam. In the IBE with clay texture the amounts of soluble P, extracted with $\mathrm{NH}_{4} \mathrm{Cl}$ were highest, although different from Mehlich 1-extractable amounts.

Index terms: Amazon Black Earth, soil P fractionation, upland soils, Manacapuru, Amazon soils, anthropogenic soils.
\end{abstract}

\footnotetext{
(1) Recebido para publicação em maio de 2008 e aprovado em junho de 2009.

(2) Doutorando do Programa de Pós-Graduação em Solos e Nutrição de Plantas do Departamento de Solo, Universidade Federal de Viçosa - UFV. Av. PH Rolfs, sn, CEP 36570-000 Viçosa (MG). Bolsista da Fundação de Amparo a Pesquisa do Estado do Amazonas - FAPEAM. Email: klebersonws@gmail.com

${ }^{(3)}$ Professor Adjunto, Faculdade de Ciências Agrárias, Universidade Federal do Amazonas - UFAM. Av. General Rodrigo Otávio 3000, CEP 69077-000 Manaus (AM). E-mail: hedinaldo@ufam.edu.br

(4) Professor Associado, Departamento de Solos, UFV. Bolsista do CNPq. E-mail: carlos.schaefer@solos.ufv.br

(5) Pesquisador da Embrapa Amazônia Ocidental, Rod. AM 010, km 29, CEP 69010-970 Manaus (AM). E-mail: wenceslau@cpaa.embrapa.br

(6) Pesquisadora da Embrapa Cerrados - CPAC. BR 020, Km 18, CEP 73310-970 Planaltina (DF). E-mail: karina.pulrolnik@cpac.embrapa.br

(7) Doutorando em Solos e Nutrição de Plantas, Departamento de Solos, UFV. Bolsista CNPq. E-mail: guilhermeudi@yahoo.com.br
} 


\title{
RESUMO: FORMAS DE FÓSFORO EM TERRAS PRETAS DE ÍNDIO CULTIVADAS (ANTROSSOLOS), COM DIFERENTES GRANULOMETRIAS, NA AMAZÔNIA BRASILEIRA
}

\begin{abstract}
Apesar da importância agrícola das Terras Pretas de Índio (TPI) na Amazônia-solos de origem pré-colombiana que ocorrem na região do vale do Amazonas / Solimões, cuja fertilidade está relacionada a elevados teores de $P$, Ca e outros nutrientes - há poucos estudos que relacionem textura e fertilidade nas TPI. Com o objetivo de avaliar os teores totais de P, as formas químicas predominantes e o estádio de transformação desse elemento, foram estudados perfis de TPI situados em áreas com solos de granulometria variável, bem como perfis de solos adjacentes às TPI como referência. A diferença textural do solo nos diferentes sitios estudados indica reflexos na fertilidade, na transformação das formas primárias de Pe, consequentemente, nas formas predominantes de P. Em solo de TPI com granulometria variando entre argilosa e muito argilosa foram observados maiores teores de P total e maiores teores da forma primária de P (P-Ca). No sítio de Rio Preto da Eva, com granulometria variando entre franco-arenosa e franco-argiloarenosa, de maneira geral, observaram-se maiores teores de $P$-Al e menores de $P$ total. As TPI do sítio de granulometria mais argilosa apresentaram maiores teores de $P$ solúvel, extraídos com $\mathrm{NH}_{4} \mathrm{Cl}$, os quais são diferentes dos teores extraídos com Mehlich-1.
\end{abstract}

Termos de indexação: Terra Preta da Amazônia, fracionamento de P, solos de terra firme, Manacapuru, Solos da Amazônia, solos antropogênicos.

\section{INTRODUCTION}

The so-called Indian Black Earth (IBE) stands for anthropogenically influenced soils that are highly important for agricultural cultivation in the Amazon valley, despite their relatively limited distribution. IBE soils were first characterized by Cunha Franco (1962), Ranzani et al. (1962), Sombroek (1966), Falesi (1970), Silva et al., (1970), and Bennema (1977), followed by detailed studies of Smith (1980), Eden et al. (1984), Kern (1988), Kern \& Kämpf (1989), Zech et al. (1979), Pabst (1991), Kern \& Costa (1997), Lima et al., (2002), and Schaefer et al. (2004). In most studies, the IBE fertility was very high, particularly for elements such as $\mathrm{P}$ and $\mathrm{Ca}$, which are usually depleted in the Amazon soils of well-drained Terra Firme. The highest Ca value reported so far reached $52 \mathrm{cmol}_{\mathrm{c}} / \mathrm{kg}$ in an IBE, in Belterra (Pabst, 1991), and the lowest $1 \mathrm{cmol}_{\mathrm{c}} \mathrm{kg}^{-1}$, in a degraded, cultivated IBE, in Colombia (Eden et al., 1984). The values reported in literature range from $1,370 \mathrm{mg} \mathrm{kg}^{-1} \mathrm{P}$ in Caxiuanã, to a maximum of $3,537 \mathrm{mg} \mathrm{kg}^{-1}$ in the Manaus region (Lima et al., 2002).

The occurrence of these Anthrosols in Amazonia (IBE) has long been documented (Katzer, 1933; Gourou, 1949; Sombroek, 1966; Ranzani et al., 1970; Eden et al., 1984; Andrade, 1986), yet many aspects of the chemistry of IBE under cultivation remain unknown. Near Manacapuru and elsewhere in the mid-Amazon valley, there are many discontinuous pockets of well-drained Tertiary plateaus, where Xanthic Oxisols (Yellow Latosols) are overlain by IBE deposits containing archaeological artifacts such as pottery fragments, weathered bones and organic remains. These patches of highly fertile Anthrosols are locally and regionally important and even today, they are intensively cultivated by local "Caboclos", highlighting their importance in the social and ecological Amazon landscape (Figure 1). Elsewhere in the Amazon region, IBE occur on sandy soil in isolated patches of very limited extension.

Detailed studies on the chemical status of IBE soils of different texture can help answer questions about phosphorous dynamics, human carrying capacity of the soil, settlement patterns and pre-Colombian landuses of Amazon people, amongst others, as recently shown by Lima et al. (2002).

The aim of this paper was to characterize the $\mathrm{P}$ fractions of Terra Preta Anthrosols with different textures (clayey to sandy), highlighting the integration of these IBE with the neighboring floodplain, in the mid-Amazon valley, and emphasizing the implications of these ancient anthrosols for long-term cultivation.

\section{MATERIAL AND METHODS}

\section{Studied areas}

In the lower Solimões river, in the vicinity of the Manacapuru river and lake, two contrasting environments are found: (1) the Holocene floodplain (Várzea), locally up to a width of $60 \mathrm{~km}$, formed by young sedimentary deposits of varying textures, mostly silty clays, in a landscape dominated by channels, floodplain lakes, alluvial plains, inundated flats and low terraces, displaying a dendritic to subdendritic drainage pattern and flat topography. (2) Another environment, called "terra firme", represents upland, well-drained plateaux of deeply 
weathered soils (Latosols) overlying pre-weathered, mature sediments of the Late Cretaceous Alter do Chão Formation (sandstone, soft claystone), under gently undulating to flat topography. The drainage network is typically dendritic to sub-rectangular, and drainage channels are little dissected (Radambrasil, 1978). In the low plateaus, Argisols (Ultisols) and Latosols (Oxisols) are largely dominant, with elongated patches of Plinthosols with scarps and bluffs mainly along the borders of the floodplain. Hydromorphic depressions on the top of the plateaus also develop deep sandy Spodosols in places due to intense podzolization of the Latosol mantle. Regardless of the texture, all soils are deeply weathered, nutrient-poor and acid. The sedimentary sequence of the Alter do Chão Formation is mature, consists of Tertiary sediments, is kaolinite and quartz-rich, and soils are very similar. In contrast, Várzea soils, derived from sediments of Andean origin, are chemically rich, mostly eutric Fluvic Neosols (Entisols), 2:1 clay-rich and silty soils. In the higher terraces farther away from the recent floodplain, Cambisols and Plinthosols are found, associated with Gleysols (Schaefer et al., 2000).

IBE was studied at two sites: the first in Laranjal, a community on an upland plateau near the banks of the Solimões river, close to the chemically rich floodplain, near the town of Manacapuru (IBEs 1 and 2), overlying deep weathered Yellow Latosols. This site represents the IBE closest to the floodplain Solimões river, in the wetland (Várzea), where soils are highly fertile and have a high human carrying capacity, food resources are abundant and high quality pottery clay. These sites were therefore occupied with denser population during pre-Colombian times, creating rich middens along the Terra Firme borders. The second site is located far away from the Amazon/ Solimões floodplain, on the farm Jiquitaia, in Rio Preto da Eva, near the river with the same name (IBEs 3 and 4 ) (Figura 1). The soils in the region are sandy, mostly podzolized Yellow to Red-yellow Argisols, and Spodosols, the environment is very leached and chemically-poor, and food resources are scarce and patchy.

All IBE sites are traditionally cultivated by local people, but the IBE soils in Jiquitaia are more degraded by cultivation than in Laranjal. The parent material of both sites is the Alter do Chão Formation. At the Laranjal and Jiquitaia sites, two soils were selected and sampled, in the layers 0-20, 20-40 and 40-60 cm. In addition, non-anthropogenic adjacent reference soils were also collected for comparative studies.

According to the Brazilian System of Soil Classification (Embrapa, 1999) and Soil Taxonomy (USDA, 1999) the following soil types were found at the Laranjal site: Anthropic Yellow Argisol (Anthropic Xanthic Kandiudult) (IBE1), Anthropic Yellow Latosol (Anthropic Xanthic Kandiudox) (IBE2), and Yellow Latosol (Xanthic Kandiudox, the reference soil of the Laranjal site). At the Jiquitáia site: Yellow Argisol (Anthropic (IBE3), Yellow Argisol (Anthropic Xanthic Kandiudult) (IBE4) and Yellow Argisol (Xanthic Kandiudult, the reference soil of the Jiquitaia site).

\section{Physical and chemical analyses}

Routine chemical analyses $(\mathrm{pH}$, available $\mathrm{P}$, exchangeable $\mathrm{Ca}^{2+}, \mathrm{Mg}^{2+}, \mathrm{K}^{+}, \mathrm{Al}^{3+}, \mathrm{H}+\mathrm{Al}$, and micronutrients $\mathrm{Fe}, \mathrm{Zn}, \mathrm{Mn}$, and $\mathrm{Cu}$ ) were carried out by standard international procedures (Embrapa, 1997). Total organic carbon was determined according to Yoemans \& Bremner (1988).

Total $\mathrm{P}$ was determined as described by Kuo (1996) and $\mathrm{P}$ fractionation was carried out according to a modified procedure of Kelly et al. (1983) (Figure 2), described below.

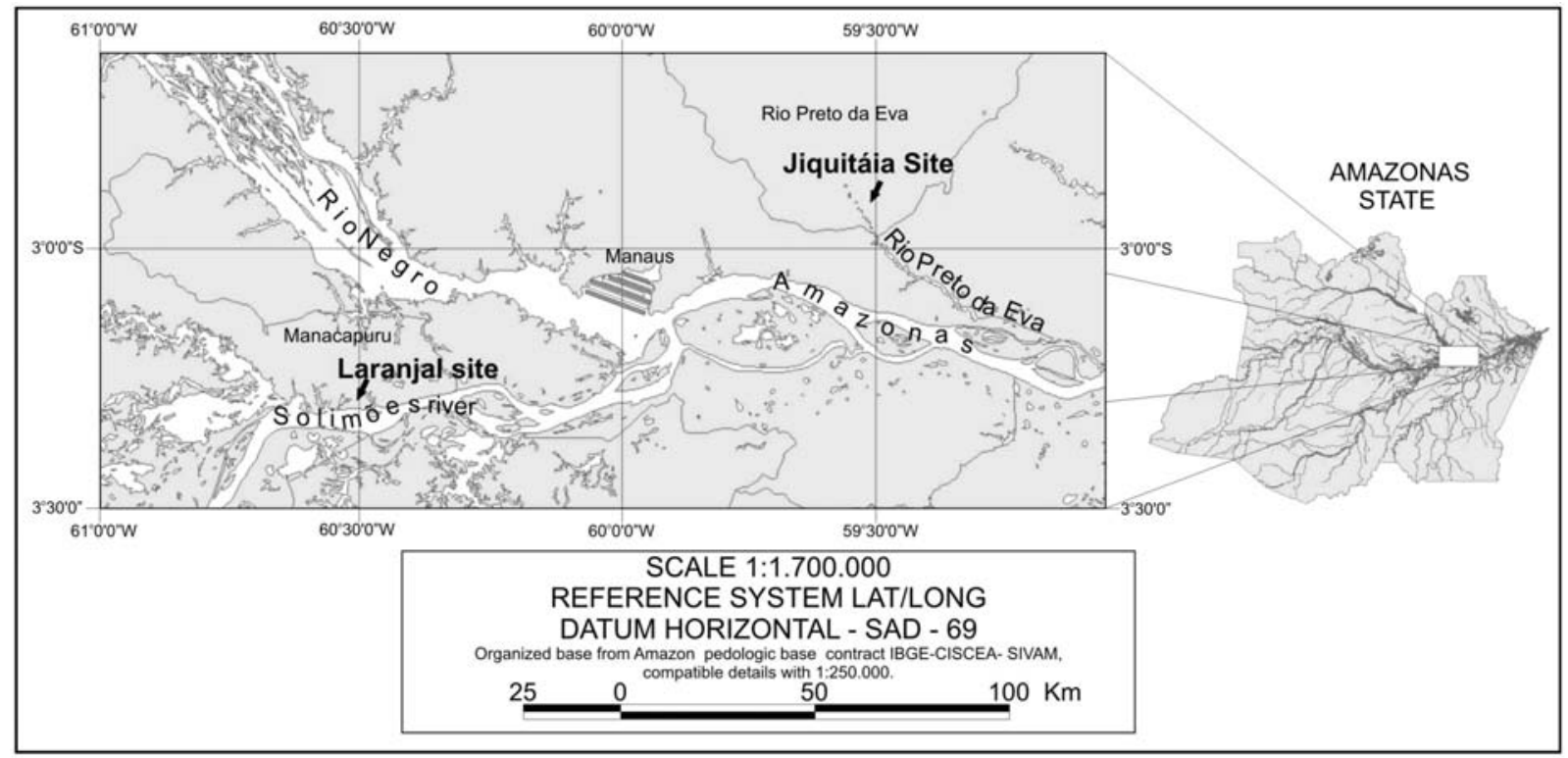

Figure 1. Location of studied area. 


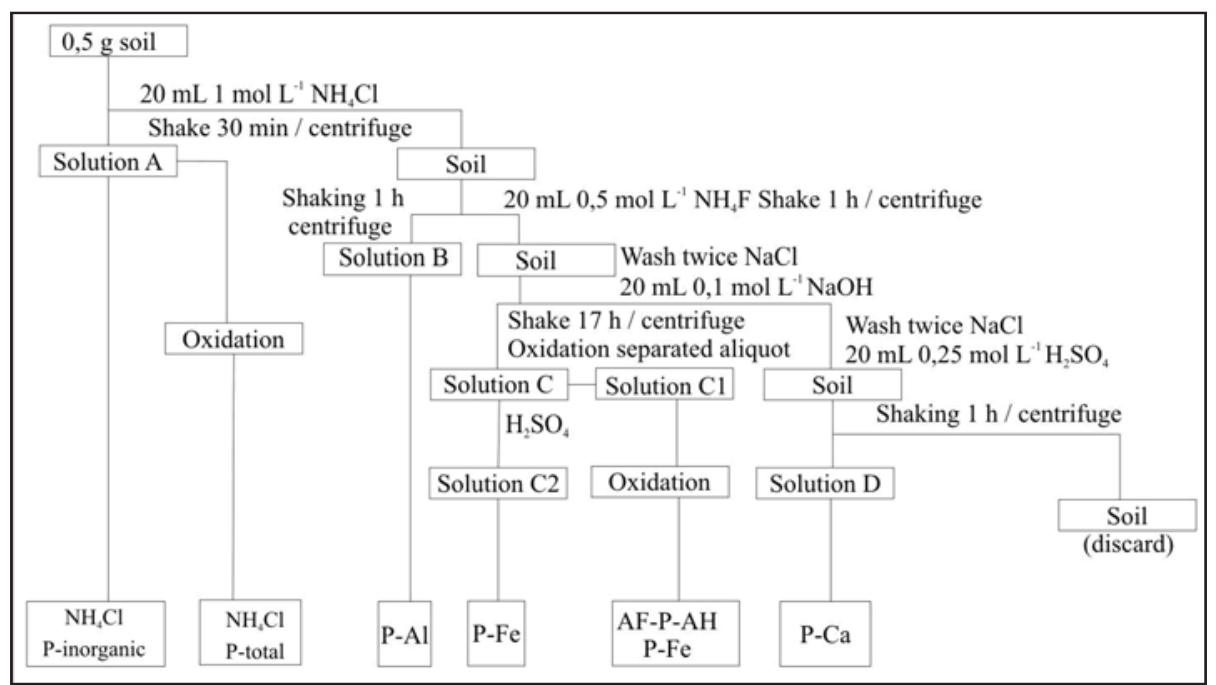

Figure 2. P fractionation diagram (adapted from Kelly et al., 1983).

Initially, the soil was treated with $1 \mathrm{~mol} \mathrm{~L}^{-1} \mathrm{NH}_{4} \mathrm{Cl}$ extraction solution for $30 \mathrm{~min}$ and shaken, for the extraction of easily-available, soluble inorganic P. Thereafter, the soil material was centrifuged and the supernatant collected for $\mathrm{P}$ determination. One aliquot was separated, oxidated by $\mathrm{H}_{2} \mathrm{O}_{2}$ and the total $\mathrm{P}$ extracted by $1 \mathrm{~mol} \mathrm{~L}^{-1} \mathrm{NH}_{4} \mathrm{Cl}$ determined. Then a neutral $0.5 \mathrm{~mol} \mathrm{~L}^{-1} \mathrm{NH}_{4} \mathrm{~F}$ solution ( $\mathrm{pH} 7.0$ adjusted with $\mathrm{NH}_{4} \mathrm{OH}$ ) was added to the soil. The mixture was shaken for $1 \mathrm{~h}$, centrifuged and P-Al in the supernatant determined. After double washing with a $\mathrm{NaCl}$ saturated solution to eliminate excess $\mathrm{NH}_{4} \mathrm{~F}$, a $0.1 \mathrm{~mol} \mathrm{~L}^{-1} \mathrm{NaOH}$ solution was added, and the washed sample shaken for $17 \mathrm{~h}$.

Onother aliquot was taken to determine P-humic acid plus P-Fe. The remaining solution was acidified with a few drops of concentrated $\mathrm{H}_{2} \mathrm{SO}_{4}$ until the humic and fulvic acids floculated, and then centrifuged. An additional aliquot was collected to determine $\mathrm{P}-\mathrm{Fe}$. After washing with saturated $\mathrm{NaCl}$ and adding a $0.25 \mathrm{~mol} \mathrm{~L}^{-1} \mathrm{H}_{2} \mathrm{SO}_{4}$ solution, $\mathrm{P}$-Ca was determined. All analytical determinations of $\mathrm{P}$ in solution were carried out by colorimetry.

\section{RESULTS AND DISCUSSION}

\section{Textural analyses}

The textural composition of the soils from the Laranjal site was clayey, with around $500 \mathrm{~g} \mathrm{~kg}^{-1}$ clay in the surface $(0-20 \mathrm{~cm})$, and between 530 and $680 \mathrm{~g} \mathrm{~kg}^{-1}$ below $20 \mathrm{~cm}$. The silt fraction varied from 20 - $60 \mathrm{~g} \mathrm{~kg}^{-1}$, with values decreasing with depth. The sand fraction varied in a range of 410-450 $\mathrm{g} \mathrm{kg}^{-1}$ in the surface, decreasing to a value close to $300 \mathrm{~g} \mathrm{~kg}^{-1}$ in subsurface layer (Table 1).
In contrast, the texture of the IBE from Rio Preto da Eva was predominantly sandy-loam, with predominant contribution of sand fraction in the surface. The clay fraction varied from $150-170 \mathrm{~g} \mathrm{~kg}^{-1}$ in the surface layers and the sand fraction from 800 $850 \mathrm{~g} \mathrm{~kg}^{-1}$ in the surface layers and $730-800 \mathrm{~g} \mathrm{~kg}^{-1}$ in the deeper layers.

In both areas there is less clay at the surface, indicating an active process of podzolization (clay eluviation) or, alternatively, greater weathering and clay destruction. We suggest that the process of IBE formation was related with continued surface burning, which may be associated with the genesis of anthropic, sandy horizons (Au horizon), corroborating Teixeira $\&$ Martins (2003). A cultivated soil subjected to very high temperatures may induce a fusion of organic and mineral particles, resulting in a higher concentration of sand particles (Sertzu \& Sanchez, 1978; Ketterings et al., 2000).

\section{Chemical analyses}

The chemical analysis revealed consistently higher fertility levels in the IBE than in the adjacent nonanthropogenic reference soils, especially regarding $\mathrm{Ca}$ and $\mathrm{P}$ amounts, and less in exchangeable $\mathrm{Mg}$. On the other hand, little differences were observed for exchangeable $\mathrm{K}^{+}$between IBE and adjacent soils, contrary to previous studies of IBE in the same region (Lima et al., 2002).

Among the two studied IBEs, the average fertility of Laranjal IBE (clayey) was greater than in IBE from the Jiquitaia site (sandy) (Table 2). The greater amounts of exchangeable $\mathrm{Ca}, \mathrm{Mg}$ and available $\mathrm{P}$ in the Laranjal are supposedly related to its proximity to the richer alluvial plain of the Solimões river, where food/fish resources are naturally more abundant, resulting in greater chemical fertility of IBE closer to the Amazon/Solimões floodplain. 
Table 1. Textural characteristics of IBE soils

\begin{tabular}{|c|c|c|c|c|c|}
\hline Depth & $\begin{array}{l}\text { Coarse sand } \\
2,00-1,00 \mathrm{~mm}\end{array}$ & $\begin{array}{c}\text { Fine sand } \\
1,00-0,05 \mathrm{~mm}\end{array}$ & $\begin{array}{c}\text { Silt } \\
0,05-0,002 \mathrm{~mm}\end{array}$ & $\begin{array}{c}\text { Clay } \\
>0,002 \mathrm{~mm}\end{array}$ & Textural class \\
\hline & & & & & \\
\hline \multicolumn{6}{|c|}{$\overline{\text { Arqueo-Anthrosol Hortic, clayey, mesotrophic, mesic IBE1 (Laranjal Site) }}$} \\
\hline $0-20$ & 230 & 170 & 60 & 540 & Clayey \\
\hline $20-40$ & 180 & 150 & 50 & 620 & Very clayey \\
\hline $40-60$ & 180 & 140 & 50 & 630 & Very clayey \\
\hline \multicolumn{6}{|c|}{ Arqueo-Anthrosol Hortic clayey, eutrophic, cumúlic IBE2 (Laranjal Site) } \\
\hline $0-20$ & 240 & 170 & 60 & 530 & Clayey \\
\hline $20-40$ & 240 & 140 & 40 & 580 & Clayey \\
\hline $40-60$ & 190 & 140 & 40 & 630 & Very clayey \\
\hline \multicolumn{6}{|c|}{ Yellow Latosol (Xanthic Kandiudox) (Laranjal Site) } \\
\hline $0-20$ & 250 & 190 & 50 & 510 & Clayey \\
\hline $20-40$ & 180 & 130 & 30 & 660 & Very clayey \\
\hline $40-60$ & 170 & 120 & 30 & 680 & Very clayey \\
\hline \multicolumn{6}{|c|}{ Arqueo-Anthrosol Hortic sandy, mesotrophic, mesic IBE3 (Jiquitaia Site Rio Preto da Eva) } \\
\hline $0-20$ & 450 & 400 & 20 & 130 & Loamy sand \\
\hline $20-40$ & 450 & 380 & 20 & 150 & Loamy sand \\
\hline $40-60$ & 390 & 340 & 30 & 240 & Sandy Clay loam \\
\hline \multicolumn{6}{|c|}{ Arqueo-Anthrosol Hortic sandy, mesotrophic, mesic IBE4 (Jiquitaia Site Rio Preto da Eva) } \\
\hline $0-20$ & 420 & 410 & 30 & 140 & Loamy sand \\
\hline $20-40$ & 450 & 370 & 20 & 160 & Loamy sand \\
\hline $40-60$ & 430 & 370 & 30 & 170 & Loamy sand \\
\hline \multicolumn{6}{|c|}{ Yellow Argisol (Anthropic Xanthic Kandiudult) (Jiquitaia Site Rio Preto) } \\
\hline $0-20$ & 500 & 300 & 30 & 170 & Loamy sand \\
\hline $20-40$ & 470 & 280 & 30 & 220 & Sandy Clay loam \\
\hline $40-60$ & 470 & 270 & 30 & 230 & Sandy Clay loam \\
\hline
\end{tabular}

Table 2. Chemical characteristics of IBE soils

\begin{tabular}{|c|c|c|c|c|c|c|c|c|c|c|c|c|c|}
\hline \multirow{2}{*}{ Depth } & \multicolumn{2}{|c|}{ pH } & \multirow{2}{*}{$\mathbf{P}^{(1)}$} & \multirow{2}{*}{$\mathrm{Ca}^{2+}$} & \multirow{2}{*}{$\mathrm{Mg}^{2+}$} & \multirow{2}{*}{$\mathbf{K}^{+}$} & \multirow{2}{*}{$\mathbf{F e}$} & \multirow{2}{*}{$\mathbf{Z n}$} & \multirow{2}{*}{ Mn } & \multirow{2}{*}{$\mathrm{Cu}$} & \multirow{2}{*}{$\mathrm{Al}^{3+}$} & \multirow{2}{*}{$\mathbf{H}+\mathbf{A l}$} & \multirow{2}{*}{$\mathbf{C}$} \\
\hline & $\mathrm{H}_{2} \mathrm{O}$ & $\mathrm{KCl}$ & & & & & & & & & & & \\
\hline \multirow[t]{2}{*}{$\mathrm{cm}$} & & & $\mathrm{mg} \mathrm{kg}^{-1}$ & - & $\mathrm{ol}_{\mathrm{c}} \mathrm{kg}^{-1}$ & - & & - mg & $b^{-1}$ & - & $-\mathrm{cm}$ & $\mathrm{cg}^{-1}-$ & dag $\mathrm{kg}^{-1}$ \\
\hline & \multicolumn{12}{|c|}{ Arqueo-Anthrosol Hortic, clayey, mesotrophic, mesic IBE1 (Laranjal Site) } & \\
\hline $0-20$ & 4,81 & 4,03 & 131 & 5 & 2 & 0,09 & 92 & 45 & 599 & 2 & 0 & 0 & 3 \\
\hline $20-40$ & 4,84 & 3,92 & 208 & 2 & 0 & 0,08 & 115 & 29 & 347 & 5 & 0 & 1 & 2 \\
\hline $40-60$ & 4,62 & 4,05 & 210 & 1 & 0 & 0,04 & 145 & 17 & 166 & 6 & 0 & 1 & 1 \\
\hline \multicolumn{14}{|c|}{ Arqueo-Anthrosol Hortic clayey, eutrophic, cumúlic IBE2 (Laranjal Site) } \\
\hline $0-20$ & 5,80 & 5,10 & 286 & 9 & 1 & 0,1 & 66 & 295 & 833 & 9 & 0 & 0 & 4 \\
\hline $20-40$ & 5,60 & 5,25 & 302 & 9 & 1 & 0,08 & 73 & 275 & 629 & 11 & 0 & 0 & 3 \\
\hline $40-60$ & 5,65 & 5,00 & 287 & 9 & 1 & 0,06 & 84 & 325 & 431 & 15 & 0 & 0 & 3 \\
\hline \multicolumn{14}{|c|}{ Yellow Latosol (Xanthic Kandiudox) (Laranjal Site) } \\
\hline $0-20$ & 4,40 & 3,65 & 10 & 1 & 0 & 0,05 & 185 & 7 & 46 & 2 & 1 & 2 & 3 \\
\hline $20-40$ & 4,20 & 3,85 & 5 & 0 & 0 & 0,03 & 200 & 3 & 35 & 3 & 1 & 2 & 2 \\
\hline $40-60$ & 4,50 & 4,00 & 4 & 0 & 0 & 0,03 & 120 & 5 & 28 & 2 & 1 & 1 & 1 \\
\hline \multicolumn{14}{|c|}{ Arqueo-Anthrosol Hortic sandy, mesotrophic, mesic IBE3 (Jiquitaia Site Rio Preto da Eva) } \\
\hline $0-20$ & 6,00 & 4,71 & 213 & 3 & 1 & 0,05 & 78 & 66 & 537 & 7 & 0 & 0 & 1 \\
\hline $20-40$ & 5,50 & 4,30 & 122 & 0 & 0 & 0,03 & 161 & 21 & 274 & 6 & 0 & 0 & 0 \\
\hline $40-60$ & 5,30 & 4,20 & 60 & 0 & 0 & 0,03 & 253 & 15 & 120 & 8 & 0 & 0 & 0 \\
\hline \multicolumn{14}{|c|}{ Arqueo-Anthrosol Hortic sandy, mesotrophic, mesic IBE4 (Jiquitaia Site Rio Preto da Eva) } \\
\hline $0-20$ & 5,70 & 4,05 & 195 & 1 & 0 & 0,06 & 59 & 63 & 562 & 0 & 0 & 1 & 2 \\
\hline $20-40$ & 5,30 & 4,00 & 156 & 0 & 0 & 0,04 & 53 & 45 & 415 & 0 & 1 & 1 & 2 \\
\hline $40-60$ & 5,20 & 4,00 & 155 & 0 & 0 & 0,04 & 54 & 42 & 405 & 0 & 1 & 1 & 2 \\
\hline \multicolumn{14}{|c|}{ Yellow Argisol (Anthropic Xanthic Kandiudult) (Jiquitaia Site Rio Preto) } \\
\hline $0-20$ & 4,20 & 3,80 & 20 & 0 & 0 & 0,09 & 130 & 4 & 105 & 5 & 1 & 2 & 2 \\
\hline $20-40$ & 4,30 & 4,00 & 20 & 0 & 0 & 0,05 & 150 & 2 & 182 & 3 & 1 & 1 & 1 \\
\hline $40-60$ & 4,30 & 3,90 & 33 & 0 & 0 & 0,06 & 281 & 1 & 110 & 10 & 1 & 1 & 0 \\
\hline
\end{tabular}

(1) P-Mehlich, available $\mathrm{P}$. 
Conversely, at the Jiquitaia site the IBE soils are consistently chemically poorer, due to the sandy nature and a much greater distance from the highly fertile alluvial plains. These sandy IBE soils are therefore quickly degraded by cultivation, compared with the richer IBE sites near the Amazonas/Solimões alluvial plain.

Mehlich-1 extractable $P$ in IBE, in the layers 0-20 and $20-40 \mathrm{~cm}$, varied between 122 and $302 \mathrm{mg} \mathrm{kg}^{-1}$, respectively, whereas the non-anthropogenic reference soils contained between 5 and $20 \mathrm{mg} \mathrm{kg}^{-1} \mathrm{P}$. These results suggest that, although no morphological evidence of typical IBE soils was observed in the adjacent soils, these reference soils were to some degree influenced anthropogenically, given that typical terra firme soils contain less than $5 \mathrm{mg} \mathrm{kg}^{-1}$ Mehlich-extractable P (Rodrigues, 1996; Schaefer et al., 2000).

Also, we observed relatively high $\mathrm{P}$ amounts in IBE soils, even at a depth of $60 \mathrm{~cm}$. For example, in the Laranjal IBE, the $\mathrm{P}$ amounts were highest at 40 $60 \mathrm{~cm}$, indicating chemical depletion or degradation at the surface, and intense pedoturbation, as observed by Kern \& Kämpf (1989), Lima (2001), Schaefer et al., 2004 .

The incorporation of $\mathrm{P}-\mathrm{Ca} / \mathrm{P}-\mathrm{Al}$ with increasing depth was clearly demonstrated by micro morphological studies of clayey IBE of the Manacapuru/Laranjal (Schaefer et al., 2004). Other authors have attributed the variation of $\mathrm{P}$ amounts in deeper layers to sedimentary variations related to temporal abandonment of sites, and variations in population (Sjoberg, 1976). In addition, erosion was also considered to influence $\mathrm{P}$ depletion at the surface (Lima, 2001).

Phosphorus mobility may be enhanced by greater soil organic matter (SOM) accumulation in the anthropogenic A horizon, since organic acids adsorbed to $\mathrm{Fe} / \mathrm{Al}$ oxides may block $\mathrm{P}$ adsorption sites (Iyamuremye \& Dick, 1996). However, the anionic nature of SOM may, in turn, favor $\mathrm{P}$ adsorption by adsorbed $\mathrm{Al} / \mathrm{Fe}$ and $\mathrm{Ca}$. This mobility may also result from the high $\mathrm{P}$ inputs at the surface, surpassing the plant uptake capacity, and increasing the potential for leaching losses (Lima, 2001).

In agreement with previous IBE studies, the Zn and Mn micronutrients were markedly greater in IBE than in the non-anthropogenic reference soils (40 times for $\mathrm{Zn}$ and 20 times for $\mathrm{Mn}$ ). On average, the IBE soils of the Laranjal site contained 60 times more $\mathrm{Zn}$ than adjacent soil.

The Jiquitáia IBE 3 was 15 times richer in Zn than adjacent soil. This confirms the usefulness of $\mathrm{Zn}$ as a chemical signature of IBE, complementary to $P$ and Ca levels. Among other factors, the low Zn mobility in soils with high OM in anthropic surface horizons contributes to this pattern. On the other hand, in the IBE and adjacent soils, the extractable Fe and
Mn were not very different, and Fe extracted by Mehlich-1 was even greater in adjacent soils, for both sites. This can be attributed to an intensified reaction of the extractor in SOM and P-rich soils, reducing the effective Fe concentration in solution.

The greatest amount of organic carbon (OC) was found in the Laranjal IBE 2 soil, whereas IBE 1 showed similar OC amounts compared with adjacent soil. Although no clear evidence of anthropogenic influences (bones fragments, pottery remains) was observed in the reference soils, its proximity to the IBE 1 and 2 suggest a possible effect of extended cultivation and burning of this area, indicating the presence of "Terra Mulata", a weakly anthropic soil. These soils are usually enriched with pirogenic carbon (Black carbon) (Woods \& McCann, 1999) derived from slash-and-burn practices, but with little deposition of $\mathrm{P}$ and $\mathrm{Ca}$-rich residues. IBE 3 of the Jiquitaia site, contained the lowest OC, even lower than the adjacent soil, which was attributed to continued cultivation and its sandy texture, which does not allow OM stabilization in soil, facilitating erosion losses.

\section{$P$ fractions}

Presumably, the primary $\mathrm{P}$ source in IBE were biogenic apatite (fish, mammals and turtle bones) as well as human bones incorporated into the soils through occasional disposals or burials by preColombian people, as demonstrated by Schaefer et al. (2004) and Lima et al. (2002).

The amounts of soluble $\mathrm{P}\left(\mathrm{NH}_{4} \mathrm{Cl}\right.$-extractable $)$ in clayey IBE (Laranjal) were higher than in sandy IBE (Jiquitáia) (Table 3). However, the total P- $\mathrm{NH}_{4} \mathrm{Cl}$ extractable amounts in all IBE was lower than Mehlich-1-extractable P, due to an overestimation of available $\mathrm{P}$ in soils with high total $\mathrm{P}$. On the other hand, the amounts extracted by total $\mathrm{P}-\mathrm{NH}_{4} \mathrm{Cl}$ and $\mathrm{P}$ Mehlich-1 were closer in adjacent, nonanthropogenic soils.

Of the clay soil, the Laranjal IBE 2 showed a dominance of $\mathrm{P}-\mathrm{Ca}$, indicating less alteration of the primary bone-apatite source, and possibly, greater stability of biogenic apatite and more recent residue deposition. In IBE 1 we observed a dominance of P-Al forms, indicating a higher dissolution and reaction of the primary organic apatite, and further precipitation of Al-phosphates of unknown crystallinity. Also the amounts of primary biogenic apatite were lower in this IBE 1.

The Laranjal IBE 2 was classified as ArqueoAnthrosol, Hortic, clayey, atrophic, cumulic (Kämpf \& Kern, 2005), which is a typical IBE soil found along the Amazon/Solimões floodplain-Terra Firme border. There, P-Ca is still dominant, due to a high prehistoric input of biogenic apatite. The IBE 1 was classified as Arqueo-Anthrosol Hortic clay, mesotrophic, mesic. The higher fertility of IBE 2 may be attributed to denser population, and/or, longer 
Table 3. Total and inorganic $P$ forms

\begin{tabular}{|c|c|c|c|c|c|c|c|c|}
\hline Depth & $\mathrm{P}-\mathrm{NH}_{4} \mathrm{Cl}^{(1)}$ & $\mathrm{PT}-\mathrm{NH}_{4} \mathrm{Cl}^{(2)}$ & P-Al & P-Fe & $\mathrm{P}-\mathrm{NaOH}{ }^{(3)}$ & $\mathbf{P}-\mathbf{F A}+\mathbf{H A}^{(4)}$ & $\mathbf{P}-\mathbf{C a}$ & P-total ${ }^{(5)}$ \\
\hline \multirow[t]{2}{*}{$\mathrm{cm}$} & \multicolumn{8}{|c|}{$-\mathrm{mg} \mathrm{kg}^{-1}$} \\
\hline & \multicolumn{8}{|c|}{ Arqueo-Anthrosol Hortic, clayey, mesotrophic, mesic IBE1 (Laranjal Site) } \\
\hline $0-20$ & 9,25 & 19,21 & 212,10 & 196,24 & 392,24 & 196,00 & 115,00 & 1001,05 \\
\hline $20-40$ & 8,25 & 16,23 & 245,23 & 190,45 & 347,70 & 157,25 & 106,25 & 2021,12 \\
\hline $40-60$ & 5,42 & 14,61 & 189,10 & 156,28 & 256,70 & 100,42 & 90,45 & 2052,25 \\
\hline \multicolumn{9}{|c|}{ Arqueo-Anthrosol Hortic clayey, eutrophic, cumúlic IBE2 (Laranjal Site) } \\
\hline 0-20 & 15,23 & 45,21 & 215,10 & 260,27 & 470,72 & 210,45 & 304,41 & 3005,10 \\
\hline $20-40$ & 23,25 & 52,47 & 231,15 & 235,51 & 425,26 & 189,75 & 201,83 & 3530,75 \\
\hline $40-60$ & 18,54 & 38,46 & 157,27 & 200,45 & 323,72 & 123,27 & 157,12 & 2856,40 \\
\hline \multicolumn{9}{|c|}{ Yellow Latosol (Xanthic Kandiudox) (Laranjal Site) } \\
\hline $0-20$ & 2,41 & 4,0 & 43,12 & 28,15 & 48,27 & 20,12 & 35,12 & 300,43 \\
\hline $20-40$ & 2,0 & 5,0 & 38,45 & 29,13 & 39.58 & 10,45 & 15,24 & 256,23 \\
\hline $40-60$ & 1,0 & 3,0 & 30,10 & 17,18 & 25,47 & 8,29 & 6,56 & 211,91 \\
\hline \multicolumn{9}{|c|}{ Arqueo-Anthrosol Hortic sandy, mesotrophic, mesic IBE3 (Jiquitaia Site Rio Preto da Eva) } \\
\hline $0-20$ & 8,0 & 21,23 & 190,15 & 156,12 & 281,12 & 125,00 & 195,56 & 2043,00 \\
\hline $20-40$ & 8,52 & 24,57 & 189,21 & 145,13 & 234,39 & 89,26 & 157,85 & 1956,48 \\
\hline $40-60$ & 2,4 & 11,30 & 145,42 & 100,25 & 156,79 & 56,54 & 145,64 & 1000,37 \\
\hline \multicolumn{9}{|c|}{ Arqueo-Anthrosol Hortic sandy, mesotrophic, mesic IBE4 (Jiquitaia Site Rio Preto da Eva) } \\
\hline $0-20$ & 5,24 & 12,10 & 127,12 & 99,10 & 174,22 & 75,12 & 107,45 & 1800,51 \\
\hline $20-40$ & 4,86 & 9,50 & 120,41 & 81,23 & 127,74 & 46,51 & 105,21 & 1462,15 \\
\hline $40-60$ & 3,20 & 8,26 & 100,10 & 75,00 & 109,12 & 34,12 & 90,51 & 900,58 \\
\hline \multicolumn{9}{|c|}{ Yellow Argisol (Anthropic Xanthic Kandiudult) (Jiquitaia Site Rio Preto) } \\
\hline $0-20$ & 1,0 & 9,4 & 42,10 & 12,00 & 17,11 & 5,11 & 23,20 & 200,67 \\
\hline $20-40$ & 1,0 & 8,28 & 35,46 & 9,16 & 12,27 & 3,11 & 19,25 & 152,46 \\
\hline $40-60$ & 0,5 & 7,12 & 26,27 & 5,17 & 8,31 & 3,14 & 12,43 & 135,32 \\
\hline
\end{tabular}

occupation by Indians, and greater residue deposition. In all IBEs, P-Ca contents are highest at the surface, due to top-down incorporation of organic residues, consistent with the tendency detected by Lima (2001).

In highly fertile, clayey IBE (Laranjal) the amounts of easily-extractable $\mathrm{P}\left(\mathrm{P}-\mathrm{NH}_{4} \mathrm{Cl}\right)$, with and without oxidation, are at least four times greater than those from adjacent non-anthropogenic soils. The amount of the more stable P-Al was also four times greater than in adjacent soils, whereas the amount of $\mathrm{P}-\mathrm{Fe}$ (extracted by $0.1 \mathrm{~mol} \mathrm{~L}^{-1} \mathrm{NaOH}$ ) was 6 -10 times greater, at similar depths. Since the total $P$ amounts were approximately 10 times greater in IBE 1 by the acid extraction (Kuo, 1996), the observed data indicate that most $\mathrm{P}$ eventually reacted with $\mathrm{Fe} / \mathrm{Al}$ oxihydroxides, forming more stable and less soluble compounds.

Consistently the amount of P-Ca (bone apatite) was much lower than the sum of P-Al + P-Fe forms, although generally greater than OM- complexed forms (Table 3).
The amount of $\mathrm{P}$ complexed by fulvic and humic acids (P-FA+HA) followed the amount of total P (8-10 times lower), compared with adjacent soils. On the other hand, the total $\mathrm{P}$ increased with depth, suggesting depletion with cultivation.

The amount of soluble $\mathrm{P}$ (extracted by $\mathrm{NH}_{4} \mathrm{Cl}$ ) in soil from near the Jiquitaia site were lower than in non-anthropogenic reference soils of Laranjal, indicating less anthropogenic influence in the surroundings of Jiquitaia, with time.

The P-Al contents were similar in the reference soils adjacent to the two sites. This strongly suggests less protection against $\mathrm{P}$ losses at the Jiquitaia site, due to its sandy texture and more acid $\mathrm{pH}$, not only in IBE, but also in non-anthropogenic soils. The contents of $\mathrm{P}-\mathrm{Al}$ and $\mathrm{P}-\mathrm{Fe}$ were five times greater, whereas the P-Ca contents were three times greater than in adjacent soils. On the other hand, the total $\mathrm{P}$ contents of sandy soils at Jiquitaia were lower than those from clay soils in Laranjal. In the latter site the IBEs were classified as Arqueo-anthrosol, hortic, sandy mesothrophic, mesic, at the two sampling points (Kämpf et al., 2003). 


\section{CONCLUSIONS}

1. The formation of Indian Black Earth in the Western Amazon region occurs in soils with a wide variety of textures, from sandy to clayey. Highly fertile, clayey soils near the Amazon/Solimões floodplain have consistently higher total P, P-Ca and $\mathrm{P}-\mathrm{Fe}$ forms than sandy soils from areas further away from the large floodplain. These clayey IBEs can support sustained cultivation long after IBE formation.

2. The dominance of $\mathrm{P}$-Ca forms in these clayey IBEs (Arqueo-Anthrosol, Hortic, clayey eutrophic, cumulic) indicates limited alteration and reaction of primary bone apatite, attributed to former biogenic apatite-rich anthropic inputs, in comparison with soils which received less rich inputs, found on sandy substrata, where $\mathrm{P}$ is less protected against losses. Feedback and trade-off mechanisms between IBE formation and their sustainability after long-term cultivation were observed.

\section{LITERATURE CITED}

BENNEMA, J. Soils. In: ALVIM, P.T. \& KOZLOWSKI, T.T., eds. Ecophysiology of tropical crops. New York, Academic Press, 1977. p.29-55.

CAMPANELLA, L. \& TOMASSETTI, M. Thermogravimetric and IR analysis of different extracts of humic substances. Thermochim. Acta, 170:67-80, 1990.

CUNHA FRANCO, E. "As Terras Pretas do Planalto de Santarem,” R. Soc. Agron. Veter. Pará, 8:17-21, 1962.

EMPRESA BRASILEIRA DE PESQUISA AGROPECUÁRIA EMBRAPA. Manual de métodos de análise de solo. 2.ed. Rio de Janeiro, 1997. 212p. (Embrapa Solos Documentos, 1)

EDEN, M.J.; BRAY, W.; HERRERA, L. \& MCEWAN, C. Terra Preta soils and their archaeological context in the Caqueta Basins of Southeast Colombia. Am. Antiquity, 49:125140,1984

FALESI, I.C. Solos de Monte Alegre. Belém, IPEAN, 1970. 127 p. (IPEAN. Solos da Amazônia, v. 2, n. 1)

IYAMUREMYE, F. \& DICK, R.P. Organic amendments and phosphorus sorption by soils. Adv. Agron., 56:139-185, 1996.

KÄMPF, N.; WOODS, W.I.; SOMBROEK, W.; KERN, D.C. \& CUNHA, T.J.F. Classification of Amazonian Dark Earth and other ancient anthropic soils. In: LEHMANN, J.; KERN, D.C.; GLASER, B. \& WOODS, W.I., eds. Amazonia Dark Earth. Origin, properties and management. Dordrecht, Kluwer Academic Publishers, 2003. p.77102 .
KÄMPF, N. \& KERN, D.C. O solo como registro da ocupação humana pré-histórica na Amazônia. In: VIDALTORRADO, P.; ALLEONI, L.R.F.; COOPER, M.; SILVA, A.P. \& CARDOSO, E.J., eds. Tópicos em ciência do solo. Viçosa, MG, Sociedade Brasileira de Ciência do Solo, 2005. v.4. p.277-320.

KELLY, J.; LAMBERT, M.J. \& TURNER, J. Available phosphorus forms in forest soils and their possible ecological significance. Comm. Soil Sci. Plant Anal., 14:1217-1234, 1983.

KERN, D.C. Caracterização pedológica de solos com terra preta arqueológica na Região de Oriximiná, Pará. Porto Alegre, Universidade Federal do Rio Grande do Sul, 1988. (Tese de Mestrado)

KERN, D.C. \& KÄMPF, N. Antigos assentamentos indígenas na formação de solos com terra preta arqueológica na região de Oriximiná, Pará. R. Bras. Ci. Solo, 13:219-225, 1989.

KERN, D.C. \& COSTA, M.L. Composição química de solos antropogênicos desenvolvidos em Latossolo Amarelo derivado de lateritos. Geociências, 16:141-156, 1997.

KETTERINGS, Q.M.; BIGHAM, J.M. \& LAPERCHE, V. Changes in soil mineralogy and texture caused by slashand-burn fires in Sumatra, Indonesia. Soil Sci. Soc. Am. J., 64:1108-1117, 2000.

KUO, S. Phosphorus. In: SPARKS, D.L.; PAGE, A.L.; HELMKE, P.A.; LOEPPERT, R.H.; SOLTANPOUR, P.N.; TABATABAI, M.A.; JOHNSTON, C.T. \& SUMMER, M.E., eds. Methods of soil analysis: Chemical methods. Madison, Soil Science Society of America, 1996. Part 3. p.869-919.

LEHMANN, J.; DA SILVA JR.; STEINER, C.; NEHLS, T.; ZECH, W. \& GLASER, B. Nutrient availability and leaching in an archaeological Anthrosol and a Ferralsol of the Central Amazon basin: Fertilizer, manure and charcoal amendments. Plant Soil, 249:343-357, 2003.

LIMA, H.N. Gênese, química, mineralogia e micromorfologia de solos da Amazônia Ocidental. Viçosa, MG, Universidade Federal de Viçosa, 2001. 176p. (Tese de Doutorado)

LIMA, H.N.; SCHAEFER, C.E.G.R.; MELLO, J.W.V.; GILKES, R.J. \& KER, J.C. Pedogenesis and pre-Colombian land use of "Terra Preta Anthrosols" ("Indian Black Earth") of Western Amazonia. Geoderma, 110:1-17, 2002.

McCANN, J.M.; WOODS, W.I. \& MEYER, E.W. Organic matter and Anthrosol in Amazônia: Interpreting the Amerindian legacy. In: REES, R.M.; BALL, B.C.; CAMPBELL, C.D. \& WATSON, C.A., eds. Sustainable management of soil organic matter. Wallingford, CABI Publishing, 2001. p.180189.

PABST, E. Critérios de distinção entre Terra Preta e Latossolo na região de Belterra e os seus significados para a discussão pedogenética. B. Museu Paraense Emílio Goeldi. Série Antropol., 7:5-19, 1991.

RANZANI, G.; KINJO, T. \& FREIRE, O. Ocorrência de "Plaggen Epipedon" no Brasil. B. Técnico- Científico ESALQ, 5:1-11, 1962. 
RADAMBRASIL. FOLHA SA20 MANAUS. Rio de Janeiro, Ministério das Minas e Energia - Departamento Nacional de Produção Mineral. Levantamento de Recursos Naturais, 1978. v.18.

RODRIGUES, T.E. Solos da Amazônia. In: ALVAREZ V., V.H.; FONTES, L.E.F. \& FONTES, M.P.F., eds. O solo nos grandes domínios morfoclimáticos do Brasil e o desenvolvimento sustentado. Viçosa, MG, Sociedade Brasileira de Ciência do Solo, Universidade Federal de Viçosa, 1996. p.19-60.

SCHAEFER, C.E.G.R.; LIMA, H.N.; VALE JUNIOR, J.F. \& MELLO, J.W.V. Uso dos solos e alterações na paisagem na Amazônia: Cenários e reflexões. B. Museu Paraense Emílio Goeldi. Série Ci. Terra, 12:63-104, 2000.

SCHAEFER, C.E.G.R.; LIMA, H.N.; GILKES, R.J. \& MELLO, J.W.V. Micromorphology and electron microprobe analysis of phosphorus and potassium forms of an Indian Black Earth (IBE) Anthrosol from Western Amazonia. Aust. J. Soil Res., 42:401-409, 2004.

SILVA, B.N.; ARAUJO, J.V.; RODRIGUES, T.E.; FLESI, I.C. \& REIS, R.S. Solos da área do Cacau Pirêra-Manacapuru. Inst. Pesq. Exp. Agropec. Norte, 2:1-198, 1970.

SERTZU, M. \& SANCHEZ, P.A. Effects of heating on some changes in soil properties in relation to Ethiopian land management practices. Soil Sci. Soc. Am. J., 42:940-944, 1978.
SJOBERG, A. Phosphate analysis of anthropic soils. J. Field Archaeol., 3:447-454, 1976.

SMITH, N.J.H. Anthrosols and human carrying capacity in Amazonia. Ann. Assoc. Am. Geogr., 70:553-566, 1980.

SOMBROEK, W.G. Amazon soils: A reconnaissance of the soils of the Brazilian Amazon Region. Wageningen, Centre for Agricultural Publications and Documentation, 1966.

TEIXEIRA, W.G. \& MARTINS, G.C. Soil physical characterization. In: LEHMANN, J.; KERN, D.C.; GLASER, B. \& WOODS, W.I., eds. Amazonian dark Earth: Origin, properties, management. Dordrecht, Kluwer Academic Publishers, 2003. p.271-286.

WOODS, W.I. \& McCANN, J.M. The anthropogenic origin and persistence of Amazonian Dark Earth. Yearbook. Conf. Latin Am. Geogr., 25:7-14, 1999.

YOEMANS, J.C. \& BREMNER, J.M. A rapid and precise method for routine determination of organic carbon in soil. Comm. Soil Sci. Plant Anal., 19:1467-1476, 1988.

ZECH, W.; HAUMAIER, L. \& HEMPFLING, R. Ecological aspects of soil organic matter in tropical land use. In: MCCARTHY, P.; CLAPP, C.E.; MALCOLM, R.L. \& BLOOM, P.R., eds. Humic substances in soil and crop sciences: Selected readings. Madison, American Society of Agronomy, 1990. p.187-202. 